\title{
AN INVESTIGATION OF A DETECTION METHOD FOR A SUBSURFACE CRACK IN THE OUTER RACE OF A CYLINDRICAL ROLLER BEARING
}

\section{BADANIA METODY WYKRYWANIA PĘKNIĘĆ PODPOWIERZCHNIOWYCH W ZEWNĘTRZNEJ BIEŻNI ŁOŻYSKA WALCOWEGO}

\begin{abstract}
As one of major failure modes of roller bearings due to periodic contact forces and external impulse loads, subsurface cracks caused by fatigues may produce catastrophic failures of rotating machines. Investigations of subsurface crack detection methods for roller bearings are very useful for maintenance purposes of these machines. In this study, a new detection method based on the curvature and power spectral density (PSD) of displacements is presented to detect a subsurface crack in the outer race of a cylindrical roller bearing. A dynamic finite element model of the cylindrical roller bearing with a subsurface crack in its outer race is developed using an explicit dynamics finite element software package to obtain the time-domain displacements. Differences of the curvature and PSD of displacements of the bearing without and with the subsurface crack are investigated, which are used to detect the location of the subsurface crack with different sizes in the outer race of the bearing. The results show that differences of the curvature and PSD of displacements from the measurement points on the outer race of the cylindrical roller bearing without and with the subsurface crack can be used to detect the location of the crack.
\end{abstract}

Keywords: detection method, subsurface crack, cylindrical roller bearing, power spectral density (PSD), curvature.

\begin{abstract}
Zmęczeniowe pęknięcia podpowierzchniowe, stanowiace jedna z głównych przyczyn uszkodzeń tożysk tocznych powodowanych okresowym działaniem sit kontaktowych i zewnętrznych obciażen impulsowych, moga prowadzić do katastrofalnych awarii maszyn wirnikowych. Badania metod wykrywania podpowierzchniowych pęknięć łożysk tocznych maja niezwykle istotne znaczenie dla obstugi serwisowej tych urzadzeń. W prezentowanym badaniu, zaproponowano nowa metodę detekcji podpowierzchniowych pęknięć w zewnętrznej bieżni łożyska walcowego. Metoda ta opiera się na pomiarze krzywizny oraz gęstości widmowej mocy (PSD) przemieszczeń. Opracowano dynamiczny model łożyska walcowego, w którego zewnętrznej bieżni powstało pęknięcie podpowierzchniowe. Model stworzono przy użyciu pakietu oprogramowania do analizy zjawisk szybkozmiennych metoda elementów skończonych $w$ celu określenia przemieszczeń w dziedzinie czasu. Badano różnice krzywizny i PSD przemieszczeń dla tożyska, w którym powstało pęknięcie podpowierzchniowe w bieżni zewnętrznej łożyska oraz łożyska bez takiego pęknięcia. Różnice te wykorzystano do lokalizacji pęknięć podpowierzchniowych różnych rozmiarów. Wyniki pokazuja, że różnice krzywizny i PSD przemieszczeń względem punktów pomiarowych na bieżni zewnętrznej między tożyskami walcowymi, z których jedno charakteryzujące się pęknięciem w warstwie podpowierzchniowej, a drugie nie, moga być wykorzystywane do wykrywania położenia pęknięcia.
\end{abstract}

Stowa kluczowe: metoda wykrywania podpowierzchniowych pęknięć, tożysko walcowe, widmowa gęstość mocy (PSD), krzywizna.

\section{Introduction}

Roller bearings are one of key components in various rotating machines. As one of major failure modes of the roller bearings due to periodic contact forces and external impulse loads, subsurface cracks in the bearings can significantly affect their dynamic performances $[18,29]$, and produce catastrophic failures in these machines. Detecting the subsurface cracks in the races of the bearings at an early stage enables timely maintenance works to extend the lifetime of the machine system. One of current detection methods is vibration-based damage detection based on changes in dynamic characteristics $[6,13]$. Therefore, it is helpful to investigate the subsurface crack detection method for early failure detection and diagnosis for maintenance purposes.

Many crack detection methods for rolling element bearings have been numerically and experimentally studied [21, 22, 29]. For instance, Yoshioka and Fujiwara [32] and Yoshioka [33] used the acous- tic emission and vibration methods to detect the propagation initiation and propagation time of rolling contact fatigue cracks. They denoted that the subsurface cracks can be detected by the acoustic emission method. Mano et al. [25] investigated the relationship between the growth of rolling contact fatigue cracks and load distribution on the inner race of a radial rolling bearing using a new acoustic emission source location method. They represented that the fatigue crack at the early stage would occur in a narrow area. Choudhury and Tandon [7] studied changes in the acoustic emission signal for defects with different sizes on the inner race and a roller of a cylindrical roller bearing. They denoted that the ringdown counts of the acoustic emission signal can be used to detect the defect in bearing raceways. Price et al. [27] and Schwach and Guo [31] also used the acoustic emission method to detect a subsurface crack caused by rolling contact fatigue. They also indicated that the acoustic emission method can be used to detect the subsurface crack in the bearing. Elforjani and Mba [12] used a range of time and frequency domain analysis techniques to detect a 
subsurface initiation and subsequent crack propagation. They demonstrated that the subsurface crack initiation and propagation can be detected by a time and frequency domain acoustic emission analysis. Eftekharnejad et al. [11] compared the applicability of the acoustic emission and vibration methods in monitoring a naturally degraded roller bearing. They described that the acoustic emission method was more sensitive in diagnosing incipient faults than the vibration method. Zhang et al. [34] studied the rolling contact fatigue damage process of the sprayed coating using the acoustics emission and vibration signals. Their results showed that the analysis of acoustic emission frequency and waveform can be effective approaches for investigating the rolling contact fatigue failure process.

Kumar et al. [17] analyzed the subsurface crack initiation produced by rolling contact fatigue. They indicated that the subsurface crack initiation and growth can be influenced by the plastic strains and residual stresses. Liu and Choi [19] proposed a new method to study the crack initiation life for rolling contact fatigue according to the dislocation and crack propagation. Their results showed that the fatigue life from their model was only $14 \%$ of that from the International Standard. Sawalhi and Randall [30] discussed the relationship between the subsurface crack and the spalling on the races of a rolling element bearing. They described a reasonable approximation of the measured defect widths. Kocich et al. [16] used an acoustic emission method to detect the subsurface crack initiation. Deng et al. [9] studied effects of subsurface cracks, distributing along the axial direction, on the rolling contact fatigue failure in the races of a bearing. They denoted that the subsurface crack growth ratio can be significantly influenced by the distribution density and interval. Bomidi and Sadeghi [3] and Moghaddam et al. [26] also investigated the subsurface crack initiation and propagation due the rolling contact fatigue. They indicated that a larger inclusions have a higher change to be located at the critical depth and produce damage. Most of the above research works are focused on modeling the subsurface crack initiation and propagation and detection the subsurface crack using the acoustic emission method. A few previous research works used vibration methods to detect the subsurface crack in rolling element bearings. Therefore, it is necessary to study the detection methods based on vibration signals for the subsurface crack in rolling element bearings.

A new detection method based on the curvature and power spectral density (PSD) of displacements from the measurement points on the outer race of a cylindrical roller bearing is proposed to detect the location of a subsurface crack in the outer race of the bearing in this study. The curvature method can easily detect the kinds in the structure displacements. The PSD method can give clearly understanding how a signal strength is distributed in its frequency domain. The curvature method $[24,28]$ and PSD method $[1,8,10]$ have been widely used to detect cracks and localized defects in beam structures and bearings. Therefore, in proposed detection method, the curvature and PSD of displacements are used. In the practical experiments, the displacements on the outer race of the bearing can be measured by a 3D Doppler laser vibrometers such as a Polytec PSV-500 scanning laser vibrometer. In this study, a dynamic finite element model of the cylindrical roller bearing with a subsurface crack in its outer race is developed using an explicit dynamics finite element software package to obtain the time-domain displacements since the finite element method has been widely used to formulate the cracks due to rolling contact fatigue $[2,5,15,19]$. Differences of the curvature and PSD of displacements of the bearing without and with the subsurface crack are investigated, which are used to detect the location of the subsurface crack with different sizes in the outer race of the bearing.

\section{Description of the detection method}

In order to detect a subsurface crack in the outer race of a cylindrical roller bearing, a new detection method based on the curvature and PSD of displacements from the measurement points on the outer race of the bearing is presented in this study. The measurement points on the outer race of the bearing are shown in Fig. 1. (a)

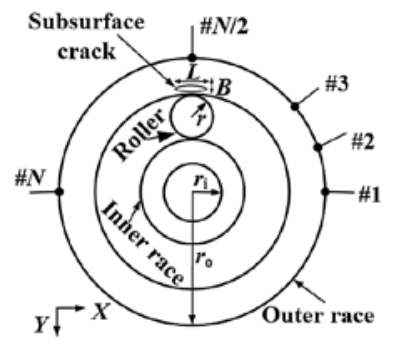

(b)

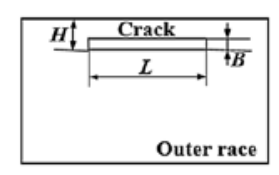

Fig. 1. (a) Measurement points on the outer race of a cylindrical roller bearing and (b) crack diagram

The radial displacement signal $R_{\mathrm{p}}$ from the measurement points on the outer race of the bearing is defined as:

$$
R_{\mathrm{p}}=\left[r_{1}, r_{2}, \cdots, r_{i}, \cdots, r_{N}\right]
$$

in which $r_{i}$ is the radial displacement of the $i$ th measurement point on the outer race of the bearing at time $t$, where $i$ is from 1 to $N$. The radial displacement signal $r_{i}$ is calculated by:

$$
r_{i}=\frac{1}{\sqrt{x_{i}^{2}+y_{i}^{2}}}\left(x_{i}, y_{i}\right) \cdot\left(\mathrm{d} x_{i}, \mathrm{~d} y_{i}\right)
$$

in which $x_{i}$ and $y_{i}$ are the coordinates in the $X$ - and $Y$-direction, respectively; $\mathrm{d} x_{i}$ and $\mathrm{d} y_{i}$ are the displacements in the $X$ - and $Y$-direction, respectively. The curvature of the radial displacement signal $R_{\mathrm{p}}$ is determined by:

$$
f^{\prime \prime}\left(r_{i}\right)=\frac{f\left(r_{i+1}\right)-2 f\left(r_{i}\right)+f\left(r_{i-1}\right)}{\Delta r^{2}}
$$

in which $f\left(r_{i+1}\right), f(r)$, and $f\left(r_{i-1}\right)$ are the curvatures of the displacement signals of the outer race at $(i+1)$ th, $i$ th, and $(i-1)$ th measurement points, respectively; and $\Delta r$ is the distance between the chosen measurement points used to calculate the curvature.

According to the calculation method for the PSD of a signal in Ref. [4], the PSD of the radial displacement signal $R_{\mathrm{p}}$ can be defined as:

$$
S(\omega)=\frac{(\Delta t)^{2}}{T}\left|\sum_{n=1}^{N} f_{n} e^{-j \omega n}\right|^{2}
$$

in which $\omega$ is the excitation frequency of the radial force $F(t)$ applied on the outer race of the bearing, which will be described in the next section; $T$ is the symbol time; $n$ is the nth date in the radial displacement signal, where $n$ is from 1 to $N$.

The difference $\Delta f$ between the curvature of the displacement signals of the bearing without and with the subsurface crack is calculated by: 


$$
\Delta f=\left|f_{\mathrm{h}}^{\prime \prime}(r)-f_{\mathrm{c}}^{\prime \prime}(r)\right|
$$

in which $f_{\mathrm{h}}^{\prime \prime}(r)$ and $f_{\mathrm{c}}^{\prime \prime}(r)$ is the curvature of the displacement signal of the bearing without and with the subsurface crack on its outer race, respectively.

The difference $\Delta S$ between the PSD of the displacement signals of the bearing without and with the subsurface crack is calculated by:

$$
\Delta S=\left|S_{\mathrm{h}}(\omega)-S_{\mathrm{c}}(\omega)\right|
$$

in which $S_{\mathrm{h}}(\omega)$ and $S_{\mathrm{c}}(\omega)$ is the PSD of the displacement signal of the bearing without and with the subsurface crack on its outer race, respectively.

\section{Finite element model}

In this study, a cylindrical roller bearing is analyzed and its parameters [23] are listed in Table 1. Geometries of the subsurface crack with different sizes in the outer race of the bearing are plotted in Fig. 2. The width $(B)$ and length $(L)$ of the crack case 1 are $0.3 \mathrm{~mm}$ and $1.85 \mathrm{~mm}$, respectively. The width and length of the crack case 2 are $0.3 \mathrm{~mm}$ and $3.65 \mathrm{~mm}$, respectively. The width and length of the crack case 3 are $0.90 \mathrm{~mm}$ and $8.1 \mathrm{~mm}$, respectively. The radial clearance of the bearing is assumed to be $0.01 \mathrm{~mm}$. The depth $(H)$ of the subsurface

Table 1. Dimensions of a cylindrical roller bearing.

\begin{tabular}{|c|c|}
\hline Parameters & Value \\
\hline Diameter of inner race $(d i, \mathrm{~mm})$ & 40.5 \\
\hline Diameter of outer race $(d o, \mathrm{~mm})$ & 62.5 \\
\hline Diameter of pitch $(D, \mathrm{~mm})$ & 51.5 \\
\hline Diameter of roller $(d, \mathrm{~mm})$ & 11 \\
\hline Effective contact length of roller $($ Ler, $\mathrm{mm})$ & 11.4 \\
\hline Number of rollers $(Z)$ & 12 \\
\hline
\end{tabular}

(a)

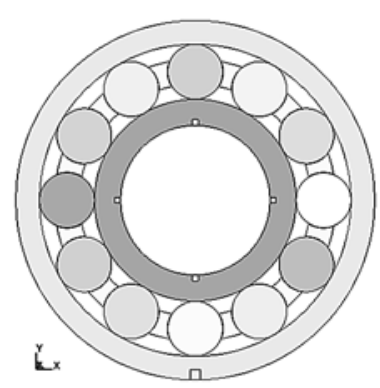

(c)

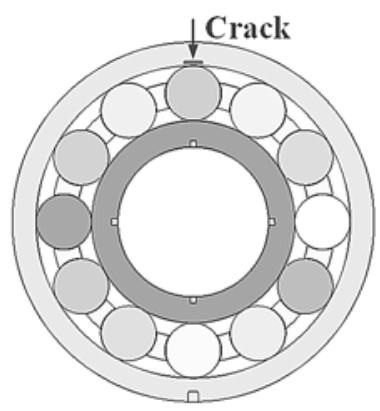

(b)

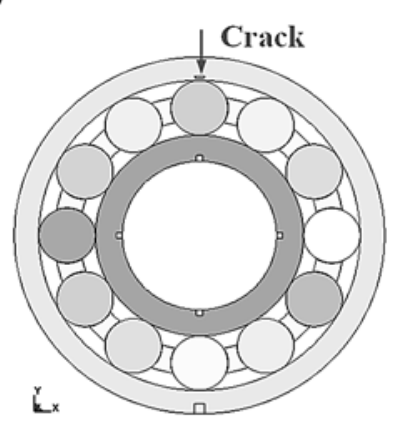

(d)

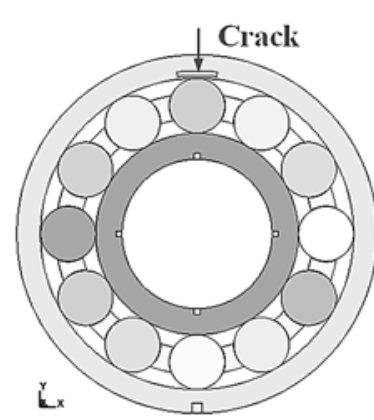

crack is $0.3 \mathrm{~mm}$, which is the distance between the crack and the surface of the outer race of the bearing. The crack is introduced into the finite element model by modelling a gap with the same sizes of the crack in the outer race. Here, the crack width, length, and depth are determined by the practical spalls in rolling element bearings used in railways and mining. The clearance between the rollers and their corresponding cage slots is assumed to be $0.05 \mathrm{~mm}$.

An explicit dynamic finite element method is used to solve the displacements of the bearing. This method was presented by using a commercially available finite element software package [14]. The finite element model of the bearing is developed using two dimensional shell elements. The two dimensional shell elements are considered as plane strain elements, which have two degrees-of-freedom at each node (translations along the $X$ - and $Y$-directions) and can be applied to simulate the roller bearing as a solid structure [23]. The finite element model of the bearing in this study has 32080 elements and 33694 nodes. The materials of the bearing structure, such as the inner race, the outer race, the rollers, and the cage, are considered as isotropic elastic materials. They are described using the material properties of steel. A linear elastic material model is used to formulate the material properties of the bearing components. The Young's modulus of the material is equal to $200 \mathrm{GPa}$, the density of the material is $7850 \mathrm{~kg} / \mathrm{m}^{3}$, and the Poisson's ratio of the material is 0.3 . In addition, the displacements of the nodes on the inner surface of the inner race of the bearing are fixed. Based on the description in Ref. [23], a dry frictional contact model is used for the contacts between the rollers and corresponding mating bearing components in the finite element model. A low friction coefficient of 0.005 is applied for the contact interfaces within the model according to the descriptions in Ref. [23]. A sinusoidal radial load is applied on the outer race of the bearing in the $Y$-direction to excite its vibrations as shown in Fig. 3, which is determined by its amplitude $F_{\mathrm{A}}$ and frequency $\omega$.

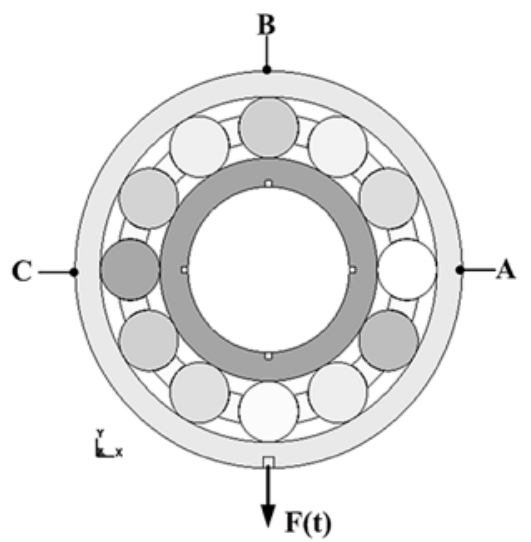

Fig. 3. Boundary conditions of the finite element model

\section{Results and discussion}

In this study, there are totally 332 measurement points from points $\mathrm{A}$ to $\mathrm{C}$ on the outer race of the cylindrical roller bearing, as shown in Fig. 3, which are evenly distributed along the circular surface of the outer race. The total simulation time is equal to $0.04 \mathrm{~s}$. The sample frequency of displacement signals from the measurement points on the outer race of the bearing is $100 \mathrm{~K}$. Effects of the amplitude and frequency of the radial load on the time-domain displacement, the curvature and PSD of radial displacements from the measurement points at the same time $t_{\mathrm{B}}$ are investigated to detect the location of the subsurface crack in the outer race of the bearing. Here, the time $t_{\mathrm{B}}$ is that when the radial displacement at point $\mathrm{B}$ reaches its maximum.

Fig. 2. Schematics of the subsurface crack with different sizes in the outer race of the bearing: (a) normal; (b) crack case 1; (c) crack case 2; and (d) crack case 3 


\subsection{Time-domain displacement signals}

Figure 4 shows the effects of the amplitude and frequency of the radial load on the time-domain displacement signals at point B in $Y$ direction from $0.015 \mathrm{~s}$ to $0.03 \mathrm{~s}$. As shown in Fig. 4, the periods of displacements are equal to those of the frequencies of the radial loads. The amplitude of displacement increases with the amplitude of radial load as shown in Fig. 4a. The frequency of radial load has slight effect on the amplitude of radial load as shown in Fig. 4b. The results show that it is difficult to detect the location of the subsurface crack in the outer race of the bearing based on the time-domain displacement from the measurement point on the outer race of the bearing.

\subsection{Curvature of the displacements}

\subsubsection{Effect of the amplitude of the radial load}

Figure 5 shows the effect of the amplitude of radial load on the curvatures of displacements from the measurement points on the outer race of the bearing for the normal case, crack cases 1,2 , and 3 . The results in Fig. 5 show that it is difficult to detect the location of the subsurface crack in the outer race of the bearing based on the curvature of displacements from the measurement points on the outer race of the bearing. To overcome this problem, the difference of the curvature of displacements of the bearing without and with the subsurface crack is calculated using the method in Eq. (5). Figure 6 shows the effect of the amplitude of radial load on differences of the curvatures of displacements of the bearing without and with the subsurface crack for crack cases 1, 2, and 3. As shown in Fig. 6, a peak at the center location of the crack zone (the point number is 167) can be observed in the difference of the curvature of displacements of the bearing without and with the subsurface crack, whose amplitude increases with the amplitude of the radial load. The results in Fig. 6 show that the differences of the curvatures of displacements of the bearing can be used to detect the location of the subsurface crack in the outer race of the bearing, and the curvature method can be more sensitive to detect the subsurface crack when a larger radial load applied on the outer race of the bearing.

\subsubsection{Effect of the frequency of the radial load}

Figure 7 shows the effect of the frequency of the radial load on the curvature of displacements from the measurement points on the outer race of the bearing for the normal case, crack cases 1, 2, and 3. The results in Fig. 7 show that it is also difficult to detect the location of the subsurface crack in the outer race of the bearing based on the curvature of displacements of the bearing. Figure 8 shows the effect of the frequency of the radial load on difference of the curvatures of displacements of the roller bearing without and with the subsurface crack for crack cases 1, 2, and 3. As shown in Fig. 8 , a peak at the center location of the crack zone
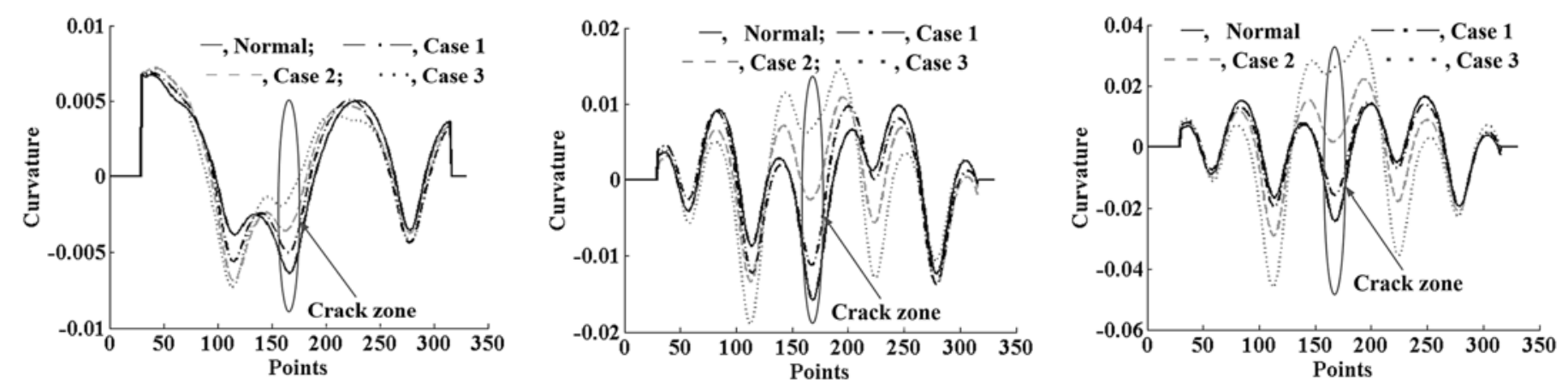

Fig. 5. Effect of the amplitude of the radial load on the curvatures of displacements from the measurement points on the outer race of the bearing for different crack cases: (a) $F=800 \mathrm{~N}$, and $\omega=400 \mathrm{~Hz}$; (b) $F=4000 \mathrm{~N}$, and $\omega=400 \mathrm{~Hz}$; and (c) $F=8000 \mathrm{~N}$, and $\omega=400 \mathrm{~Hz}$
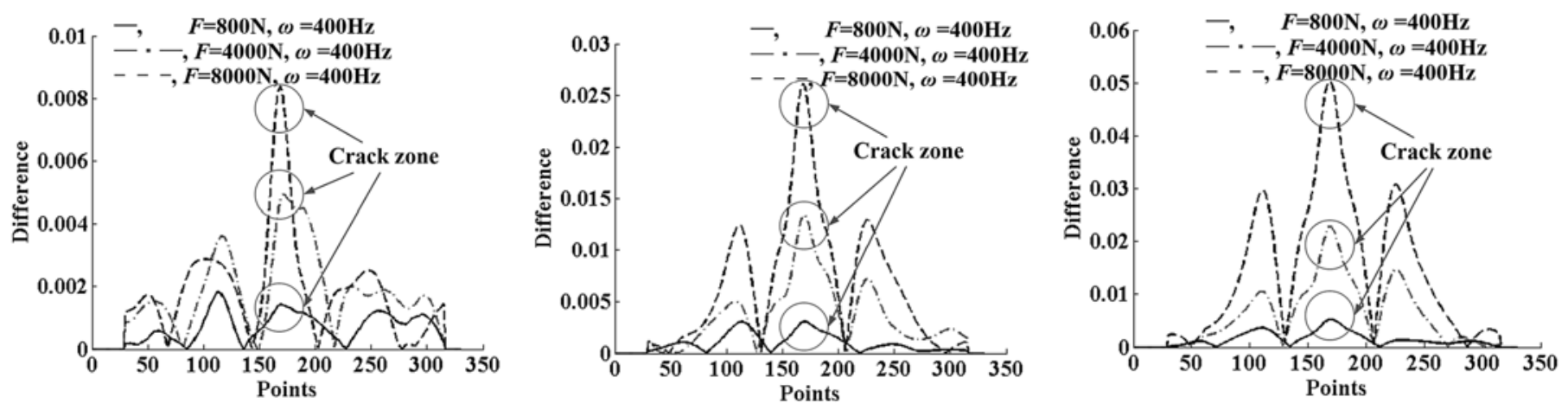

Fig. 6. Effect of the amplitude of the radial load on differences of the curvature of displacements from the measurement points on the outer race of the bearing without and with the subsurface crack for different crack cases: (a) crack case 1; (b) crack case 2; and (c) crack case 3 

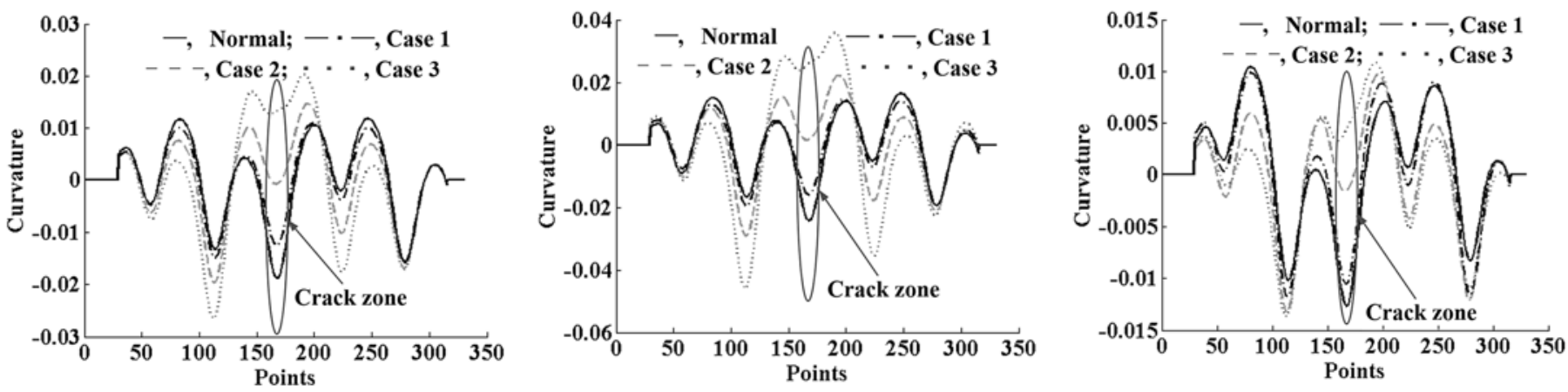

Fig. 7. Effect of the frequency of the radial load on the curvature of displacements from the measurement points on the outer race of the bearing for different crack cases: (a) $F=800 \mathrm{~N}$, and $\omega=200 \mathrm{~Hz}$; (b) $F=800 \mathrm{~N}$, and $\omega=400 \mathrm{~Hz}$; and (c) $F=800 \mathrm{~N}$, and $\omega=600 \mathrm{~Hz}$.
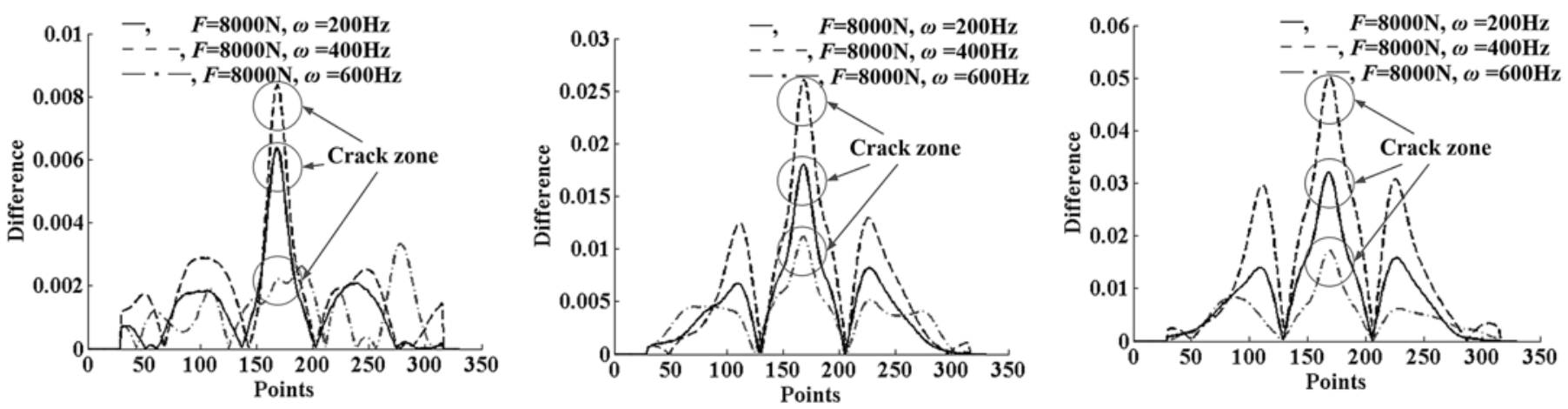

Fig. 8. Effect of the frequency of the radial load on differences of the curvatures of displacements from the measurement points on the outer race of the bearing without and with the subsurface crack for different crack cases: (a) crack case 1; (b) crack case 2; and (c) crack case 3

(the point number is also 167) can be observed in the difference of the curvature of displacements of the bearing without and with the subsurface crack too, whose amplitude increases with the amplitude of the radial load. The amplitude of the peak for the $400 \mathrm{~Hz}$ is larger than those for the other two frequencies. The amplitude of the peak for the $200 \mathrm{~Hz}$ is larger than that for the $600 \mathrm{~Hz}$. The results in Fig. 8 also show that the difference of the curvature of displacements of the bearing can be used to detect the location of the subsurface crack in the outer race of the bearing.

\subsection{PSD of the displacement}

\subsubsection{Effect of the amplitude of the radial load}

Figure 9 shows the effect of the amplitude of the radial load on the PSD of displacements from the measurement points on the outer race of the bearing for the normal case, crack cases 1,2 , and 3 . The results in Fig. 9 show that it is difficult to detect the location of the subsurface crack in the outer race of the bearing based on the PSD of displacements of the bearing. To overcome this problem, the difference of the PSD of displacements of the bearing without and with the subsurface crack is calculated using the method in Eq. (6). Figure 10 shows the effect of the amplitude of the radial load on differences of the PSD of displacements of the bearing without and with the subsurface crack for crack cases 1, 2, and 3. As shown in Fig. 10, a peak at the center location of the crack zone (the point number is also 167) can be observed in the difference of the PSD of displacements of the bearing without and with the subsurface crack, whose amplitude increases with the amplitude of the radial load. Moreover, as shown in Fig. 10a, the PSD is not very sensitive for the subsurface crack with a small size under a smaller radial load, which means a lager radial load is needed to detect the subsurface crack with a small size using the PSD method. The results in Fig. 10 show that the difference of the PSD of displacements of the bearing can be used to detect the location of the subsurface crack in the outer race of the bearing for a larger radial load, and the PSD method has slight sensitive to detect the subsurface crack when a smaller radial load applied on the outer race of the bearing.
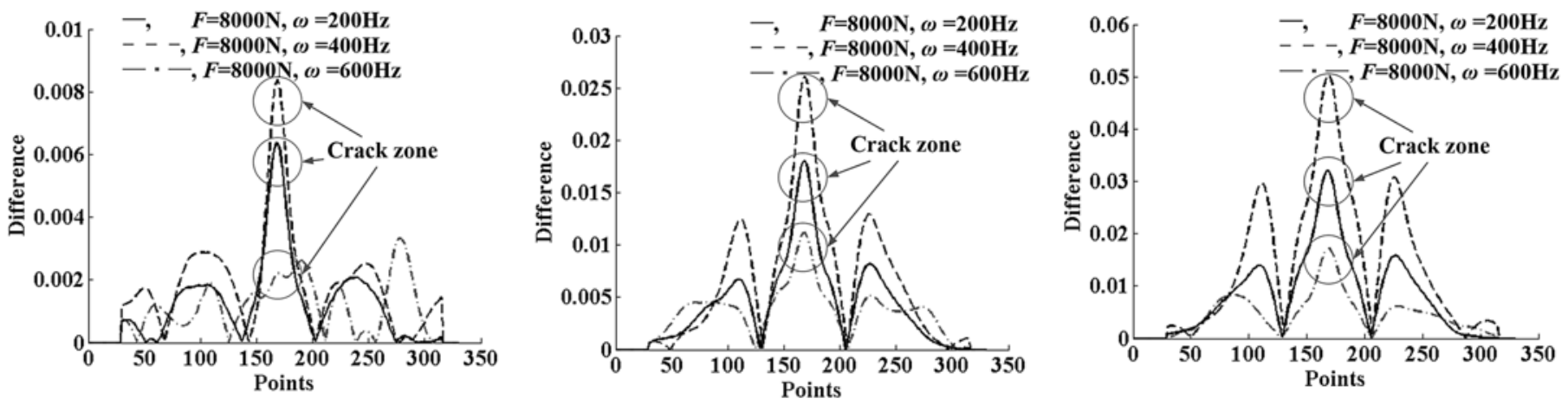

Fig. 8. Effect of the frequency of the radial load on differences of the curvatures of displacements from the measurement points on the outer race of the bearing without and with the subsurface crack for different crack cases: (a) crack case 1; (b) crack case 2; and (c) crack case 3 

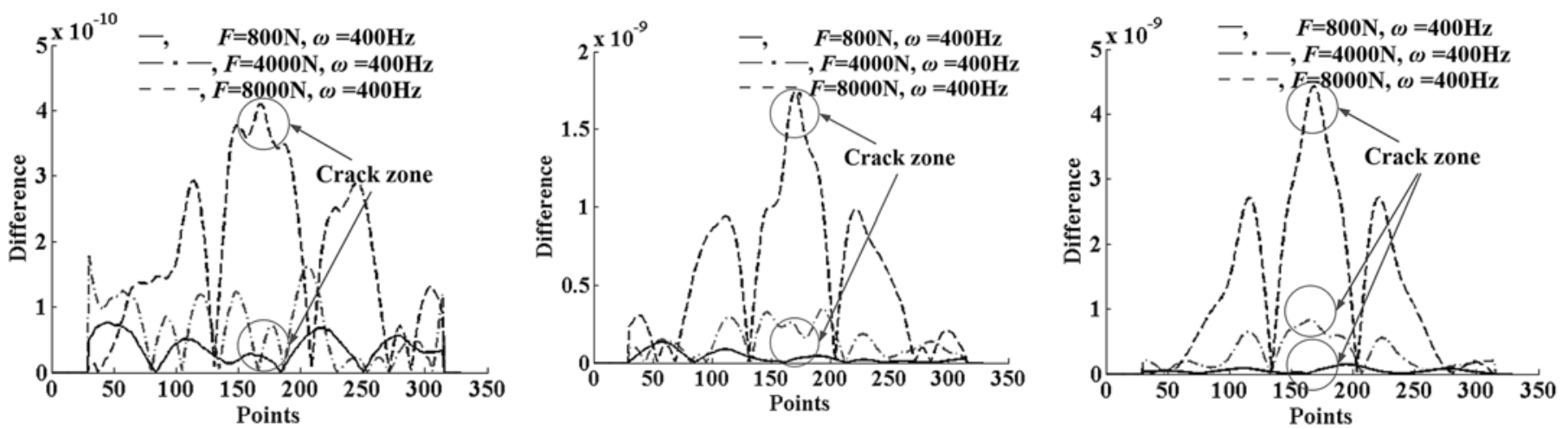

Fig. 9. Effect of the amplitude of the radial load on differences of the PSD of displacements from the measurement points on the outer race of the bearing without and with the subsurface crack for different crack cases: (a) crack case 1; (b) crack case 2; and (c) crack case 3
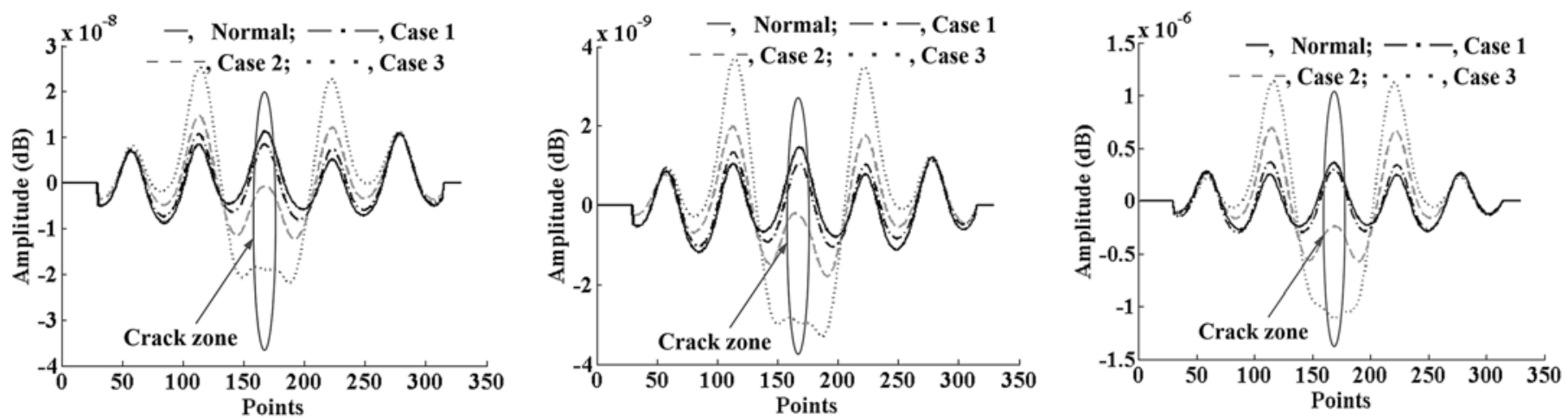

Fig. 10. Effect of the amplitude of the radial load on differences of the PSD of the displacements from the measurement points on the outer race of the bearing without and with the subsurface crack for different crack cases: (a) crack case 1; (b) crack case 2; and (c) crack case 3
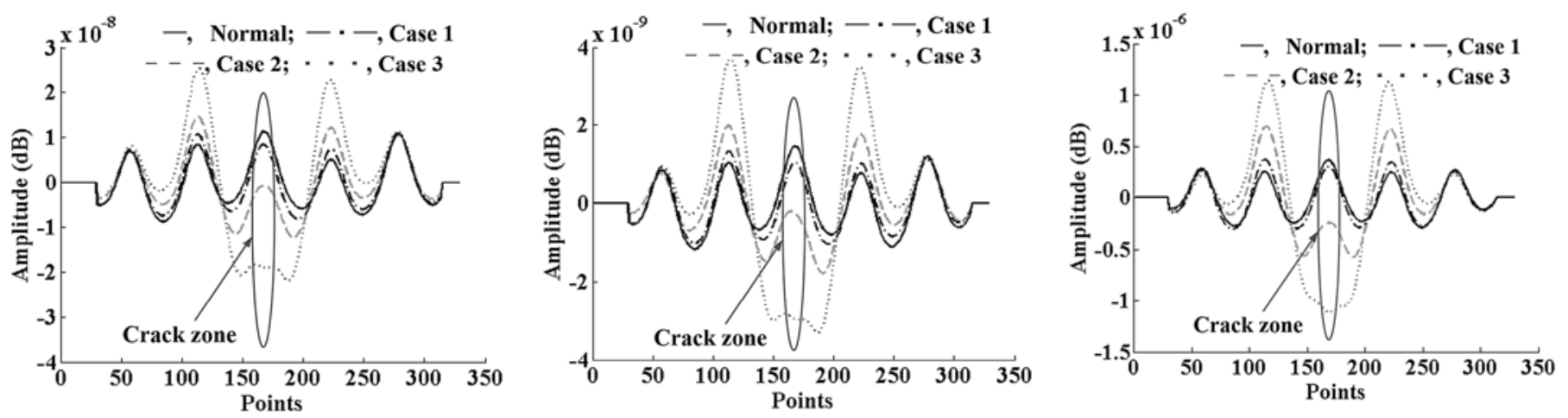

Fig. 11. Effect of the frequency of the radial load on the PSD of displacements from the measurement points on the outer race of the bearing for different crack cases: (a) $F=800 \mathrm{~N}$, and $\omega=200 \mathrm{~Hz}$; (b) $F=800 \mathrm{~N}$, and $\omega=400 \mathrm{~Hz}$; and (c) $F=800 \mathrm{~N}$, and $\omega=600 \mathrm{~Hz}$
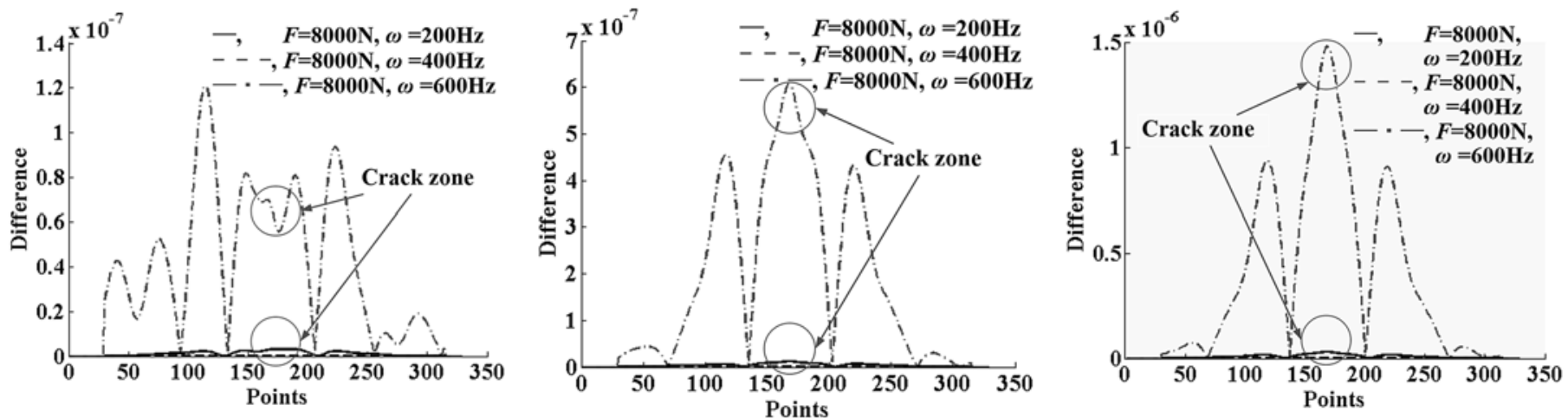

Fig. 12. Effect of the frequency of the radial load on differences of the PSD of displacements from the measurement points on the outer race of the bearing without and with the subsurface crack for different crack cases: (a) crack case 1; (b) crack case 2; (c) crack case 3 

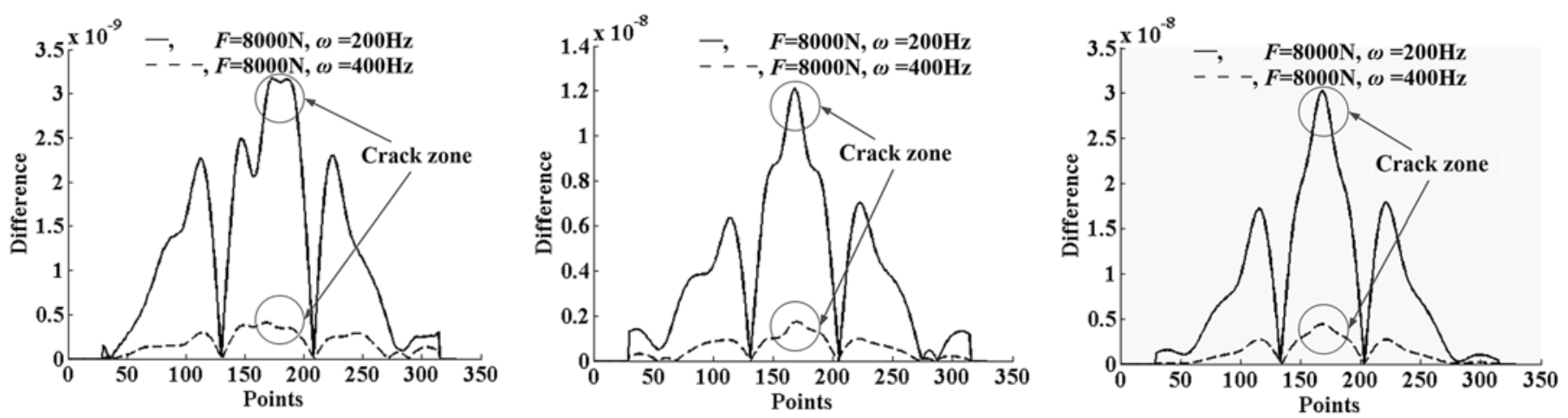

Fig. 12. Effect of the frequency of the radial load on differences of the PSD of displacements from the measurement points on the outer race of the bearing without and with the subsurface crack for different crack cases: (d) enlarge view of (a); (e) enlarge view of (b); and (f) enlarge view of (c)

\subsubsection{Effect of the frequency of the radial load}

Figure 11 shows the effect of the frequency of the radial load on the PSD of displacements from the measurement points on the outer race of the bearing for the normal case, crack cases 1,2 , and 3 . The results in Fig. 11 show that it is also difficult to detect the location of the subsurface crack in the outer race of the bearing based on the PSD of displacements of the bearing. Figure 12 shows the effect of the frequency of the radial load on the difference of the PSD of displacements of the bearing without and with the subsurface crack for crack cases 1,2, and 3. As shown in Fig. 12, a peak at the center location of the crack zone (the point number is also 167) can be observed in the difference of the PSD of displacement of the bearing without and with the subsurface crack, whose amplitude increases with the frequency of the radial load. The results in Fig. 12 show that the differences of the PSD of displacements of the bearing can be used to detect the location of the subsurface crack in the outer race of the bearing for a larger radial load, and the PSD method is more sensitive to detect the subsurface crack when a radial load with a higher frequency applied on the outer race of the bearing.

\section{Conclusions}

A new detection method based on the curvature and PSD methods is used to detect a subsurface crack in the outer race of a cylindrical roller bearing. A dynamic finite element model of the bearing with a subsurface crack in its outer race is developed to obtain the timedomain displacements. Differences of the curvature and PSD of dis-

\section{Appendix A}

\section{Nomenclature}

$B \quad$ Width of subsurface crack, mm

c Crack case

$D$ Diameter of pitch, mm

$d$ Diameter of roller, $\mathrm{mm}$

$d_{\mathrm{i}}$ Diameter of inner race, $\mathrm{mm}$

$d_{\mathrm{o}}$ Diameter of outer race, $\mathrm{mm}$

$d x_{i}$ Displacement in X-direction, $\mathrm{mm}$

$d y_{i}$ Displacement in Y-direction, $\mathrm{mm}$

$F_{\text {A }}$ Amplitude of radial load, N

$F(t)$ Radial load, N

$f^{\prime \prime}(r)$ Curvature of radial displacement signal

$h$ Normal case

$i \quad$ Measurement point number

$L \quad$ Length of subsurface crack, $\mathrm{mm}$

$L_{\mathrm{er}}$ Effective contact length of roller, $\mathrm{mm}$ placements of the bearing without and with the crack are investigated to detect the location of the crack in the outer race of the bearing. The following conclusions can be draw from this study:

1) It is difficult to detect a subsurface crack in outer race of a cylindrical roller bearings based on the time-domain displacements of the outer race of the bearing.

2) A peak at the center location of the crack zone can be observed in the difference of the curvature of the displacement of the bearing without and with the subsurface crack, whose amplitude increases with the amplitude of the radial load applied on the outer race of the bearing. The curvature method can be used to detect the subsurface crack in the outer race of the bearing.

3) Differences of curvature and PSD of displacements from the measurement points on the outer race can be used to detect the location of a subsurface crack in the outer race of the bearing. The curvature and PSD methods can be more sensitive to detect the subsurface crack under a larger radial load. An appropriate excitation frequency of the radial load will helpful for detecting the subsurface crack. The PSD method is not very sensitive for the subsurface crack with a small size under a smaller radial load. A lager radial load is needed to detect the subsurface crack with a small size in the outer race of the bearing using the PSD method.

\section{Acknowledgement}

The research work financed with the National Natural Science Foundation of China under Grant Numbers 51605051 and 51475053, the Fundamental Research Funds for Central Universities under Grant Numbers $106112015 C D J X Y 110007$.

$N \quad$ Number of measurement points

$R \mathrm{p}$ Radial displacement signal, $\mathrm{mm}$

$r$ Radius of roller, $\mathrm{mm}$

$r_{\mathrm{i}} \quad$ Radius of inner race, $\mathrm{mm}$

$r_{\mathrm{o}}$ Radius of outer race, $\mathrm{mm}$

$r_{i}$ radial displacement of ith measurement point, $\mathrm{mm}$

$S(\omega)$ PSD of radial displacement signal, $\mathrm{dB}$

$t$ Time, s

$x_{i}$ Coordinate in X-direction

$y_{i} \quad$ Coordinate in Y-direction

$Z$ Number of rollers

$\Delta f$ Difference of curvature of displacements

$\Delta S$ Difference of PSD of displacements, $\mathrm{dB}$

$\omega$ Frequency of radial load, $\mathrm{Hz}$ 


\section{References}

1. Antoni J., Randall R. B. - A stochastic model for simulation and diagnostics of rolling element bearings with localized faults. Journal of vibration and acoustics 2003; 125(3): 282-289, https://doi.org/10.1115/1.1569940.

2. Bogdański S., Trajer M. - A dimensionless multi-size finite element model of a rolling contact fatigue crack. Wear 2005; 258(7): 1265-1272, https://doi.org/10.1016/j.wear.2004.03.036.

3. Bomidi J. A. R., Sadeghi F. - Three-dimensional finite element elastic-plastic model for subsurface initiated spalling in rolling contacts. Journal of Tribology 2014; 136(1): 011402, https://doi.org/10.1115/1.4025841.

4. Brown R. G., Hwang P. Y. C. - Introduction to random signals and applied Kalman filtering. New York: John Wiley and Sons, 1997.

5. Canadinc D., Sehitoglu H., Verzal K. - Analysis of surface crack growth under rolling contact fatigue. International Journal of Fatigue 2008; 30(9): 1678-1689, https://doi.org/10.1016/j.ijfatigue.2007.11.002.

6. Cao H., Niu L., He Z. - Method for vibration response simulation and sensor placement optimization of a machine tool spindle system with a bearing defect. Sensors 2012; 12(7): 8732-8754, https://doi.org/10.3390/s120708732.

7. Choudhury A., Tandon N. - Application of acoustic emission technique for the detection of defects in rolling element bearings. Tribology international 2000; 33(1): 39-45, https://doi.org/10.1016/S0301-679X(00)00012-8.

8. Cusido J., Romeral L., Ortega J. A., Rosero J A. - Fault detection in induction machines using power spectral density in wavelet decomposition. Industrial Electronics, IEEE Transactions on 2008; 55(2): 633-643, https://doi.org/10.1109/TIE.2007.911960.

9. Deng S., Han X. H., Qin X. P., Huang S. - Subsurface crack propagation under rolling contact fatigue in bearing ring. Science China Technological Sciences 2013; 56(10): 2422-2432, https://doi.org/10.1007/s11431-013-5291-5.

10. Deshpande L., Sawalhi N., Randall R. B. - Gearbox bearing fault simulation using a finite element model reduction technique. Journal of Physics: Conference Series. IOP Publishing 2012; 364(1): 012082.

11. Eftekharnejad B., Carrasco M. R., Charnley B., Mba D. - The application of spectral kurtosis on acoustic emission and vibrations from a defective bearing. Mechanical Systems and Signal Processing 2011; 25(1): 266-284, https://doi.org/10.1016/j.ymssp.2010.06.010.

12. Elforjani M., Mba D. - Assessment of natural crack initiation and its propagation in slow speed bearings. Nondestructive testing and evaluation 2009; 24(3): 261-275, https://doi.org/10.1080/10589750802339687.

13. El-Thalji I., Jantunen E. - A summary of fault modelling and predictive health monitoring of rolling element bearings. Mechanical Systems and Signal Processing 2015; 60: 252-272, https://doi.org/10.1016/j.ymssp.2015.02.008.

14. Hallquist J. O. - LS-DYNA theory manual. Livermore Software Technology Corporation, 2006.

15. Kadin Y., Rychahivskyy A. V. - Modeling of surface cracks in rolling contact. Materials Science and Engineering: A 2012; 541: 143-151, https://doi.org/10.1016/j.msea.2012.02.016.

16. Kocich R., Cagala M., Crha J., Kozelsky P. - Character of acoustic emission signal generated during plastic deformation. Proc. 30th European Conf. on 'Acoustic emission testing' and 7th Int. Conf. on 'Acoustic emission', Granada, Spain. 2012.

17. Kumar A. M., Hahn G. T., Rubin C. A. - A study of subsurface crack initiation produced by rolling contact fatigue. Metallurgical Transactions A 1993; 24(2): 351-359, https://doi.org/10.1007/BF02657322.

18. Leturiondo U., Salgado .O, Galar D. - Multi-body modelling of rolling element bearings and performance evaluation with localised damage. Eksploatacja i Niezawodnosc - Maintenance and Reliability 2016; 18(4): 638-648, https://doi.org/10.17531/ein.2016.4.20.

19. Liu C. R., Choi Y. - A new methodology for predicting crack initiation life for rolling contact fatigue based on dislocation and crack propagation. International Journal of Mechanical Sciences 2008; 50(2): 117-123, https://doi.org/10.1016/j.ijmecsci.2007.07.011.

20. Liu Y., Liu L., Mahadevan S. - Analysis of subsurface crack propagation under rolling contact loading in railroad wheels using FEM. Engineering fracture mechanics 2007; 74(17): 2659-2674, https://doi.org/10.1016/j.engfracmech.2007.02.012.

21. Liu J., Shao Y. M., Zhu W. D. - A new model for the relationship between vibration characteristics caused by the time-varying contact stiffness of a deep groove ball bearing and defect sizes. Journal of Tribology 2015; 137(3): 031101, https://doi.org/10.1115/1.4029461.

22. Liu J., Shao Y. M. - A new dynamic model for vibration analysis of a ball bearing due to a localized surface defect considering edge topographies. Nonlinear Dynamics 2015; 79(2): 1329-1351, https://doi.org/10.1007/s11071-014-1745-y.

23. Liu J., Shao Y. M. - A numerical investigation of effects of defect edge discontinuities on contact forces and vibrations for a defective roller bearing. Journal of Multi-body Dynamics 2016; 230(4): 387-400, https://doi.org/10.1177/1464419315615451.

24. Lu X. B., Liu J. K., Lu Z. R. - A two-step approach for crack identification in beam. Journal of Sound and Vibration 2013; 332(2): 282-293, https://doi.org/10.1016/j.jsv.2012.08.025.

25. Mano H., Yoshioka T., Korenaga A., Yamamoto T. - Relationship between growth of rolling contact fatigue cracks and load distribution. Tribology transactions 2000; 43(3): 367-376, https://doi.org/10.1080/10402000008982352.

26. Moghaddam S. M., Sadeghi F., Paulson K., Weinzapfel N., Correns M., Bakolas V., Dinkel M. - Effect of non-metallic inclusions on butterfly wing initiation, crack formation, and spall geometry in bearing steels. International Journal of Fatigue 2015; 80: 203-215, https:// doi.org/10.1016/j.ijfatigue.2015.05.010.

27. Price E. D., Lees A. W., Friswell M. I., Roylance B. J. - Online detection of subsurface distress by acoustic emissions. Key Engineering Materials 2003; 245: 451-460, https://doi.org/10.4028/www.scientific.net/KEM.245-246.451.

28. Ratcliffe C. P. - A frequency and curvature based experimental method for locating damage in structures. Journal of vibration and acoustics 2000; 122(3): 324-329, https://doi.org/10.1115/1.1303121.

29. Sadeghi F., Jalalahmadi B., Slack T. S., Raje N., Arakere N. K. - A review of rolling contact fatigue. Journal of Tribology 2009; 131(4): 041403, https://doi.org/10.1115/1.3209132.

30. Sawalhi N., Randall R. B. - Vibration response of spalled rolling element bearings: Observations, simulations and signal processing techniques to track the spall size. Mechanical Systems and Signal Processing 2011; 25(3): 846-870, https://doi.org/10.1016/j.ymssp.2010.09.009.

31. Schwach D. W., Guo Y. B. - A fundamental study on the impact of surface integrity by hard turning on rolling contact fatigue. International journal of fatigue 2006; 28(12): 1838-1844, https://doi.org/10.1016/j.ijfatigue.2005.12.002.

32. Yoshioka T., Fujiwara T. - Measurement of propagation initiation and propagation time of rolling contact fatigue cracks by observation of acoustic emission and vibration. Tribology Series 1987; 12: 29-33, https://doi.org/10.1016/S0167-8922(08)71045-9. 
33. Yoshioka T. - Detection of rolling contact sub-surface fatigue cracks using acoustic emission technique. Lubrication Engineering 1993; 49(4): 303-308.

34. Zhang Z. Q., Li G. L., Wang H. D., Xu B. S., Piao Z. Y., Zhu L. N. - Investigation of rolling contact fatigue damage process of the coating by acoustics emission and vibration signals. Tribology International 2012; 47: 25-31, https://doi.org/10.1016/j.triboint.2011.10.002.

\section{Jing LIU}

State Key Laboratory of Mechanical Transmission, Chongqing University, Chongqing, 400030, P.R. China

College of Mechanical Engineering, Chongqing University, Chongqing, 400030, P.R. China

\section{Zhifeng SHI \\ Yimin SHAO}

State Key Laboratory of Mechanical Transmission, Chongqing University, Chongqing, 400030, P.R. China

E-mail: jliu@cqu.edu.cn, m15051980972@163.com, ymshao@cqu.edu.cn 